\title{
DESAFIOS PARA O DESENVOLVIMENTO TERRITORIAL RURAL NO ASSENTAMENTO JOÃO BATISTA II, CASTANHAL, PARÁ
}

\author{
DESAFÍOS PARA EL DESARROLLO TERRITORIAL RURAL EN \\ EL ASENTAMIENTO JOÃO BATISTA II, CASTANHAL, PARÁ
}

José Antônio Guilherme Junior
$\begin{array}{r}\text { Doutorando PPGEO/UFPA } \\ \text { jaguilhermejr@gmail.com }\end{array}$

Gilberto de Miranda Rocha

Doutor em Geografia Professor NUMA / PPGEO UFPA gilrocha@ufpa.br

Adolfo Oliveira Neto

Doutor em Geografia Professor FGC / PPGEO UFPA adolfoneto@ufpa.br

\section{Resumo}

Este trabalho discute aspectos relacionados ao desenvolvimento territorial em área de reforma agrária, tendo como base o Projeto de Assentamento João Batista II, no município de Castanhal, Estado do Pará. O foco da pesquisa foi direcionado ao histórico de produção e organização social em dois principais momentos, o acampamento e o assentamento. Ainda que o Estado, por meio das políticas de fomento à agricultura, e o MST, via ações de luta pela reforma agrária, considerem a perspectiva do desenvolvimento, é a dinâmica interna do assentamento que garante ou não sua efetivação. De acordo com os dados levantados por meio do estudo de caso, no período de 1998-2012 e 2019, no assentamento o desenvolvimento territorial esteve limitado por dificuldades na gestão dos recursos e projetos agropecuários além da fragmentação política e disputas entre as entidades de representação interna dos trabalhadores.

Palavras chaves: Desenvolvimento territorial. Assentamentos de Reforma Agrária. Produção. Organização. João Batista II.

\section{Resumen}

El trabajo aborda aspectos relacionados al desarrollo territorial en área de reforma agraria, teniendo como base empírica el Proyecto de Asentamiento João Batista II, en el municipio de Castanhal estado de Pará. El enfoque de la investigación há sido direccionada al histórico de producción y organización social en dos principales momentos: El campamento y el asentamiento. Aunque el Estado, a través de las políticas de incentivo a la agricultura y el MST, por medio de acciones de lucha por la reforma agraria, consideren la perspectiva del desarrollo, en suma es la dinámica interna del asentamiento que 
garantiza o no su efectividad. De acuerdo con los datos recogidos mediante al estudio de caso, realizados en el período de 1998 a 2012 e 2019 en el asentamiento, el desarrollo estuvo restringido por dificultades en la gestión de los recursos y proyectos agropecuários, además de la fragmentación política y conflictos entre las entidades de representación interna de los trabajadores.

Palabras claves: Desarrollo territorial. Asentamientos de Reforma Agraria. Producción. Organización. João Batista II.

\section{Introdução}

Este artigo é um desdobramento das reflexões iniciadas com a dissertação de mestrado "Reprodução camponesa em área de assentamento na Amazônia: um estudo no Assentamento João Batista II, Castanhal-Pará", cujo objetivo foi identificar, caracterizar e analisar os desafios para reprodução sócioespacial camponesa, entendida como a potencialidade de recriação econômica e política, em assentamentos rurais na Amazônia. A época, a problemática do desenvolvimento não foi analisada, papel que este artigo busca cumprir.

Debater os desafios para o desenvolvimento territorial, tendo como parâmetro um assentamento, é buscar "enxergar" os rebatimentos locais das políticas de Reforma Agrária, ou seja, sua realização prática, bem como, a adequação às necessidades das populações que vivem no campo.

A opção pelo lócus da pesquisa se deu porque o Assentamento João Batista II foi resultado de uma ação direcionada pelo Movimento dos Trabalhadores Rurais Sem Terra (MST) na mesorregião do nordeste paraense, região com histórico de colonização agrícola. O processo de territorialização local do movimento iniciou-se com a ocupação da Fazenda Tanari, estrategicamente localizada nas proximidades de Belém (75,6 Km). A mobilização iniciou em julho de 1998 e a efetivação do assentamento ocorreu em março de 2001, ocupando uma área de 2.118 ha.

Um aspecto importante, que será descrito posteriormente, foi que o MST propôs a organização do trabalho na forma coletiva, direcionando os investimentos e a maneira de produzir no interior dos núcleos. O financiamento público e os projetos agropecuários também fizeram parte da constituição do assentamento. Em síntese, partimos da premissa que esse território rural é resultado da ação de diferentes atores (Estado, Movimentos 
Sociais e beneficiários não-organizados), nem sempre convergindo no mesmo projeto, o que torna as práticas de desenvolvimento mais complexas.

Diante dessa perspectiva, a questão que norteia esse artigo é quais os desafios para o desenvolvimento territorial rural no Assentamento João Batista II, localizado no município de Castanhal, estado do Pará? Para investigar os mencionados desafios, optamos por analisar, de forma qualitativa, duas variáveis a produção e a organização do trabalho. A produção está relaciona a maneira como o trabalhador direciona sua força vital em benefício de sua reprodução, tal aspecto liga-se umbilicalmente a organização do trabalho, a correlação dessas variáveis nos auxiliam na análise o desenvolvimento territorial rural no assentamento.

A estratégia de investigação utilizada foi o estudo de caso, que se insere na pesquisa qualitativa, onde os objetos não são reduzidos a simples variáveis, mas sim, representados em sua totalidade, dentro de seus contextos cotidianos, investigando, deste modo, os sujeitos em suas práticas e interações (FLICK, 2009).

Para levantamento das informações adotamos os seguintes passos: a) revisão bibliográfica de artigos, dissertações e teses sobre o assentamento; b) pesquisa documental, momento em que consultamos o Projeto de Desenvolvimento do Assentamento (PDA) elaborado pela Empresa de Assistência Técnica e Extensão Rural do Estado do Pará (EMATER). A leitura do documento norteou as informações iniciais principalmente quanto aos projetos agropecuários e o histórico de ocupação da fazenda Tanari; c) pesquisa de campo por meio da qual realizamos as entrevistas semiestruturadas, com questões abertas e fechadas, buscando estabelecer um diálogo em que o entrevistado discorra livremente sobre os assuntos indagados. Fizemos os registros em caderno de campo, gravando as falas por meio de gravador sempre com a anuência dos entrevistados. Nesse momento também realizamos um levantamento fotográfico das propriedades e da agrovila, onde residem a maior parte dos assentados. Na descrição das entrevistas, optouse pela preservação da identidade dos sujeitos, sendo estes identificados somente pela primeira letra do nome.

Entrevistamos o total de 20 pessoas, sendo 2 líderes do MST que participaram da formação do assentamento, 2 ex-líderes de núcleo e o técnico da EMATER responsável pela área. Essas entrevistas, ocorreram em novembro de 2011 e formam importantes para identificar os assentados que possuíam produção agrícola em seus lotes. No período de janeiro e julho de 2012 realizamos as entrevistas com os 15 assentados identificados como 
produtores. As entrevistas foram realizadas tanto nos lotes, quanto na agrovila do assentamento. Em abril de 2019 retornamos ao assentamento para levantar informações sobre a realidade atual, ocasião em que tivemos algumas conversas com lideranças e moradores do assentamento, além de fazer o registro fotográfico de algumas paisagens atuais.

\section{O Desenvolvimento territorial a partir do debate paradigmático e as alternativas propostas pelo MST}

Como destacado em Oliveira Neto (2017), o desenvolvimento territorial se tornou na década de 2000 e de 2010 o grande orientador das políticas nos países subdesenvolvidos, em especial no caso brasileiro, sendo defendido por organismos multinacionais, pelo Estado brasileiro, por diversas empresas, por um grande número de pesquisadores e, também, por movimentos sociais.

No entanto, sujeitos diferentes ao defenderem este conceito, de fato, estão disputando-o a partir de suas próprias diretrizes, no que chamamos de debate paradigmático da geografia agrária brasileira (CAMPOS; FERNANDES, 2011), a partir das contribuições do Paradigma do Capitalismo Agrário (PCA) e do Paradigma da Questão Agrária (PQA).

O PCA tem como base o pensamento de Mendras (1984) e Lamarche (1998, 1993), sendo que o primeiro dá origem à tendência do agronegócio, defendendo que a industrialização da agricultura eliminou o camponês francês pela falta de competitividade da pequena propriedade, enquanto o segundo, dá origem à tendência da agricultura familiar, mostrando como os diferentes graus de integração possibilitaram a metamorfose do campesinato, transformando-o em agricultor familiar.

Por outro lado, o Paradigma da Questão Agrária, tem origem nos trabalhos de Kautsky (1986), Lênin (1985, 1980), Chayanov (2014a, 2014b, 1974), Luxemburg (1985). Kautsky e Lênin que deram origem à chamada tendência proletarista, entanto Chayanov e Luxemburg inauguram à tendência campesinista, compreendendo que, a cada novo avanço do capitalismo no campo, recria-se também as condições do campesinato se reproduzir.

Uma visão esquemática destas duas tendências pode ser vista na Figura 1. 
Figura 1 - Debate Paradigmático na Geografia Agrária Brasileira

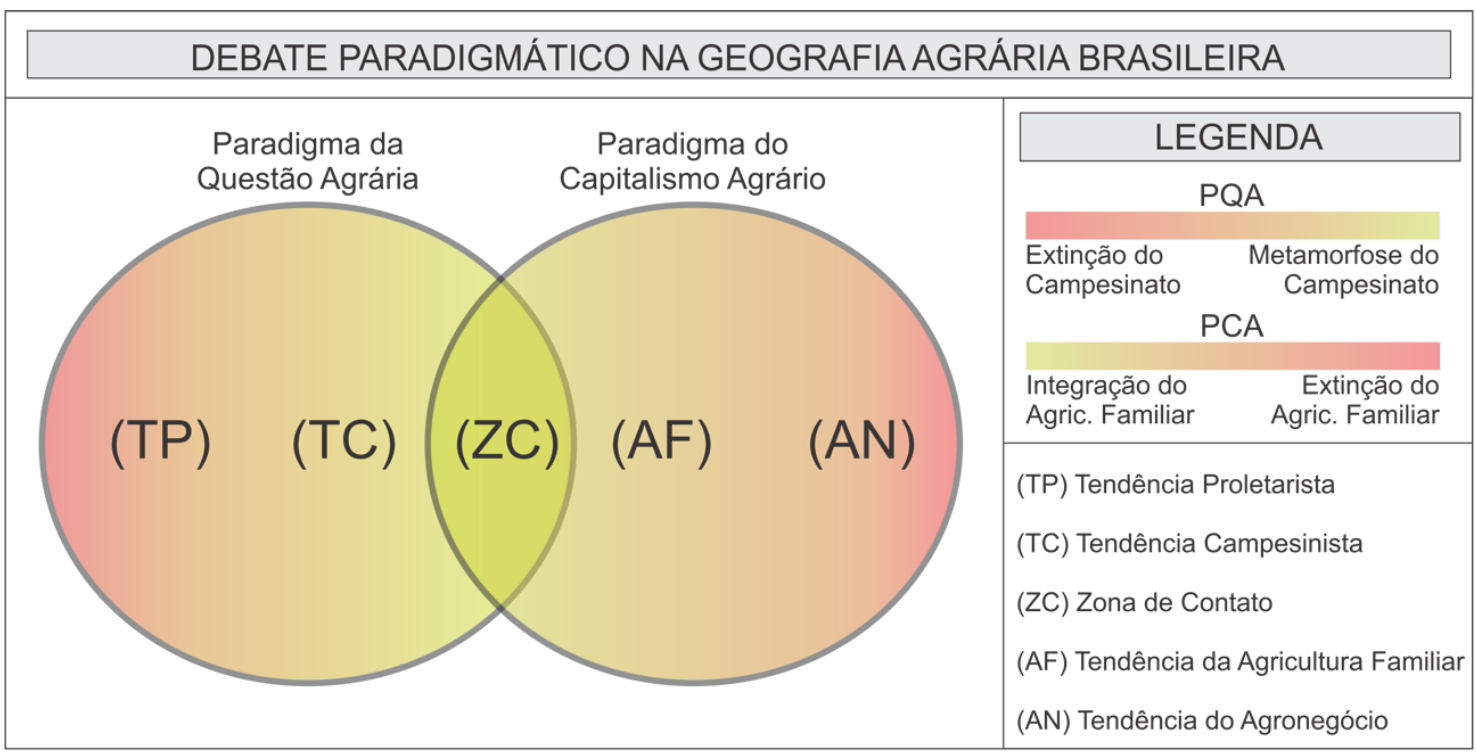

Concepção: Bernardo Mançano Fernandes.

Fonte: Oliveira Neto (2017).

Baseado nos trabalhos desenvolvidos pelo Grupo de Turim e nas orientações gerais da União Europeia para pensar o desenvolvimento do campo em seus países membros, alguns autores ganharam destaque e influenciaram o pensamento brasileiro sobre o desenvolvimento territorial, a partir do PQA, são: Abramovay (2012), Favareto (2006), Ortega (2008) e Veiga (2012), etc. Entre outras questões, e ressalvando as diferenças existentes entre eles, os autores se baseiam na visão do desenvolvimento territorial a partir de: a) o desenvolvimento como uma força guia e um pacto social construído entre os diversos sujeitos; b) o desenvolvimento territorial como um elemento capaz de ser obtido em escala local; c) a necessidade de uma visão multidimensional do desenvolvimento; d) o desenvolvimento como valorização de aspectos próprios (locais); e) desenvolvimento como dinâmica articulada a mercados dinâmicos; d) a subordinação do campesinato ao agronegócio e; e) necessidade de instituições novas e multisetoriais para articular as políticas públicas para o desenvolvimento.

Esta tendência, a partir de movimentos mais ou menos intensos, acabou influenciando um conjunto de pesquisadores importantes a pensar o rural brasileiro enfocando estas questões, como observamos em trabalhos como Sulzbacher; David (2008) e Silva; Hespanhol (2016), entre muitos outros.

Por outro lado, alguns dos autores que mais influenciaram o pensamento sobre o desenvolvimento territorial a partir da perspectiva do Paradigma da Questão Agrária 
foram Fernandes (2014, 2013), Oliveira (1986) e Brandão (2007), entre outros. Em comum, para estes autores, a problemática é posta a partir do ponto de vista da diversidade da produção camponesa, da necessidade de um paradigma produtivo no campo que considere as dinâmicas da vida, defendendo principalmente o paradigma da agroecologia e o mercado, o problema das estruturas coloniais que deixaram a sua marca e o embate pela reprodução camponesa como projeto territorial. Entre os elementos centrais desta concepção, estão: a) a luta de classes no campo; b) renda da terra, renda capitalizada da terra e apropriação do trabalho; c) controle dos recursos naturais e território; d) falta de política pública para a reprodução camponesa e; e) o agronegócio e a desestruturação dos territórios camponeses.

Essa tendência produziu uma série de trabalhos importantes para a interpretação do campo no Brasil, em especial a partir da sua conflitualidade, como Silva; Oliveira Neto (2018), Silva; Silva; Oliveira Neto, Nascimento (2017), Coelho; Camacho (2018), Coca (2015) e Bringel; Neves; Brito (2017), entre outros.

A nosso ver, associando-nos com o PQA, entendendo a necessidade de recriação camponesa a partir das suas diversas experiências de luta para a sua reprodução, um dos elementos fundamentais desta questão é a complexidade e atualidade da questão agrária, como "movimento contraditório do conjunto de problemas relativos ao desenvolvimento do capitalismo no campo e dos processos que envolvem o campesinato, que dizem respeito às lutas de resistência e aos processos de recriação" (OLIVEIRA NETO, 2017, p. 51).

Já o MST, no que diz respeito ao desenvolvimento territorial, associa-se ao PQA, defendendo uma visão anticapitalista baseado na ação coletiva, conflitualidade, multidimensionalidade do território camponês, na ação em defesa de políticas públicas, no enfrentamento da oligarquia agrária, no combate ao agronegócio e no entendimento que a questão agrária, ao longo do processo histórico brasileiro, tem se renovado com as tentativas das classes dominantes do campo de manterem seu poder sob o domínio quase feudal da terra.

No caso do Assentamento João Batista II, cabe destacar três elementos da conjuntura que influenciaram nas ações do movimento:

a) O primeiro mandato do Governo de Fernando Henrique Cardoso (1995-1998), que atacou diretamente diversos movimentos sociais e, em especial, o MST, pelo 
risco que ele representava aos interesses hegemônicos que constituíam uma parte significativa da base econômica e política que sustentava o governo;

b) A realização do $3^{\circ}$ Congresso do MST (1995), cujo lema foi "Reforma agrária: uma luta de todos", reafirmando a tese da importância da reforma agrária para a construção de um país que pudesse superar as desigualdades sociais e construir uma alternativa popular de futuro no campo e na cidade;

c) No Pará, o massacre de Eldorado do Carajás, ocorrido em abril de 1996, que levou a morte de 19 trabalhadores, se transformando em um marco internacional dos horrores contra os movimentos sociais no campo.

Os aspectos enumerados buscam exemplificar a relação do movimento com a conjuntura política. No caso do governo de Fernando Henrique, as práticas de repressão traduziram-se em ações de reintegração de posse, processos judiciais contra lideranças e uso da força policial. O aumento na repressão gerou uma intensificação das ações de ocupação de terra no período, passando de 186 no início do governo para 795 no final. A bandeira da reforma agrária ganhou maior notoriedade, sobretudo após a chacina de Eldorado e, com a pressão de órgãos internacionais para solução do problema, o MST ganha maior capital político e intensifica suas ações de ocupação em todo o estado do Pará.

Diante desses aspectos, cabe uma menção de como a noção de desenvolvimento territorial, foi elaborada pelo movimento no contexto de formação do Assentamento. Tomou-se como referência o texto da Confederação das Cooperativas de Reforma Agrária do Brasil (CONCRAB), documento que reúne proposições e direcionamentos do MST, para assentamentos e áreas rurais:

O desenvolvimento rural é a garantia de progresso econômico e social para todos os que vivem no meio rural, de uma forma sustentável e respeitando o equilíbrio de recursos naturais. De maneira a garantir melhorias permanentes das condições de vida, para todos, e não só de alguns, no aspecto material (alimentação, habitação, transporte, etc), cultural e espiritual. (CONTRAB, 1998, p.3).

Trata-se de uma proposta cuja amplitude perpassa por temas que vão deste as mudanças sociais até o uso equilibrado dos recursos naturais, a partir do paradigma da 
agroecologia. A coletividade é um elemento destacado, pois, de acordo com o movimento, somente os trabalhadores organizados podem provocar uma mudança no modelo de produção agrícola e no poder político. Trata-se, assim, de uma proposta fortemente vinculada a um programa de ação política. Como destaca Fernandes (2008), dentro de uma perspectiva apoiada no PQA, as perspectivas do desenvolvimento territorial devem ser compreendidas a partir da crítica ao modo de produção capitalista existente, portanto, um aspecto de superação sistêmica do modelo hegemônico.

Umas das principais propostas do movimento para promover o desenvolvimento territorial nos assentamentos de reforma agrária são as cooperativas agrícolas, isto é, "o jeito de juntar esforços (capital variável) de cada trabalhador rural individual" (CONCRAB, 1998, p.18-19). Existe, nesse sentido, um direcionamento na organização do trabalho, que na visão do movimento, garante maiores resultados no que diz respeito à produtividade e inserção no mercado.

Para Fabrini (2002) o cooperativismo proposto pelo MST, desconsidera a prática socioprodutiva do campesinato, nesse sentido, as cooperativas teriam um papel organizativo de superação do individualismo. Conforme destaca, "este projeto está sustentado num arcabouço teórico que reconhece a superioridade operária e as modernas relações de produção para construir um território favorável ao processo revolucionário" (FABRINI, 2002, p. 76).

A abrangência na concepção de desenvolvimento territorial rural defendida pelo MST, bem como, sua vinculação com a mudança radical da sociedade, amplia demasiadamente as ações a serem realizadas nos assentamentos. O Movimento também homogeneíza os sujeitos desconsiderando suas trajetórias laborais, ou seja, sua posição de classe pretérita, sob o pretexto de organizar uma massa revolucionária contra o capital. A abrangência desse projeto de poder, em grande medida, não coincide com o aspecto prático da família camponesa assentada, que luta por um pedaço de chão, para prover seu sustento e manutenção da família. 
O desenvolvimento territorial rural em áreas de reforma agrária: o caso do Assentamento João Batista II.

a) O acampamento: passos iniciais do processo de luta pela terra (1998-2001)

Nesse tópico três aspectos são destacados como elementos centrais, primeiramente a mobilização do MST, em segundo lugar a ocupação do latifúndio e finalmente a inserção do trabalhador na dinâmica do movimento. Para Haesbaert (2004) territorializar-se significa criar mediações espaciais que proporcionem efetivo poder sobre o processo de reprodução dos grupos sociais, no caso dos assentamentos, Fernandes (2006, p.6) evidencia que "representam um processo de territorialização na conquista da terra de trabalho contra a terra de negócio e de exploração", no pensamento deste último autor, está a ideia que o desenvolvimento territorial liga-se a projetos territoriais de classes que se evidenciam na conflitualidade de suas ações. Em conformidade com os autores supracitados compreende-se a territorialização como produto emergente das territorialidades no espaço do acampamento.

Após o massacre de Eldorado dos Carajás, o MST planejava constituir um assentamento próximo a região metropolitana e, para tanto, realizou um levantamento de possíveis imóveis que tivessem problemas relativos à titulação e que estavam em situação improdutiva. Dentre as diversas propriedades com flagrantes irregularidades, a fazenda Tanarí, no município de Castanhal, mostrou-se mais viável, pois estava bem localizada, possuía uma área que poderia assentar várias famílias e vinha sendo utilizada apenas para a especulação fundiária. O mapa-1 apresenta a localização da fazenda que depois seria desapropriada para a criação do Assentamento João Batista II, na mesorregião do Nordeste Paraense. 
Mapa 1: Assentamento João Batista II, na mesorregião do Nordeste Paraense

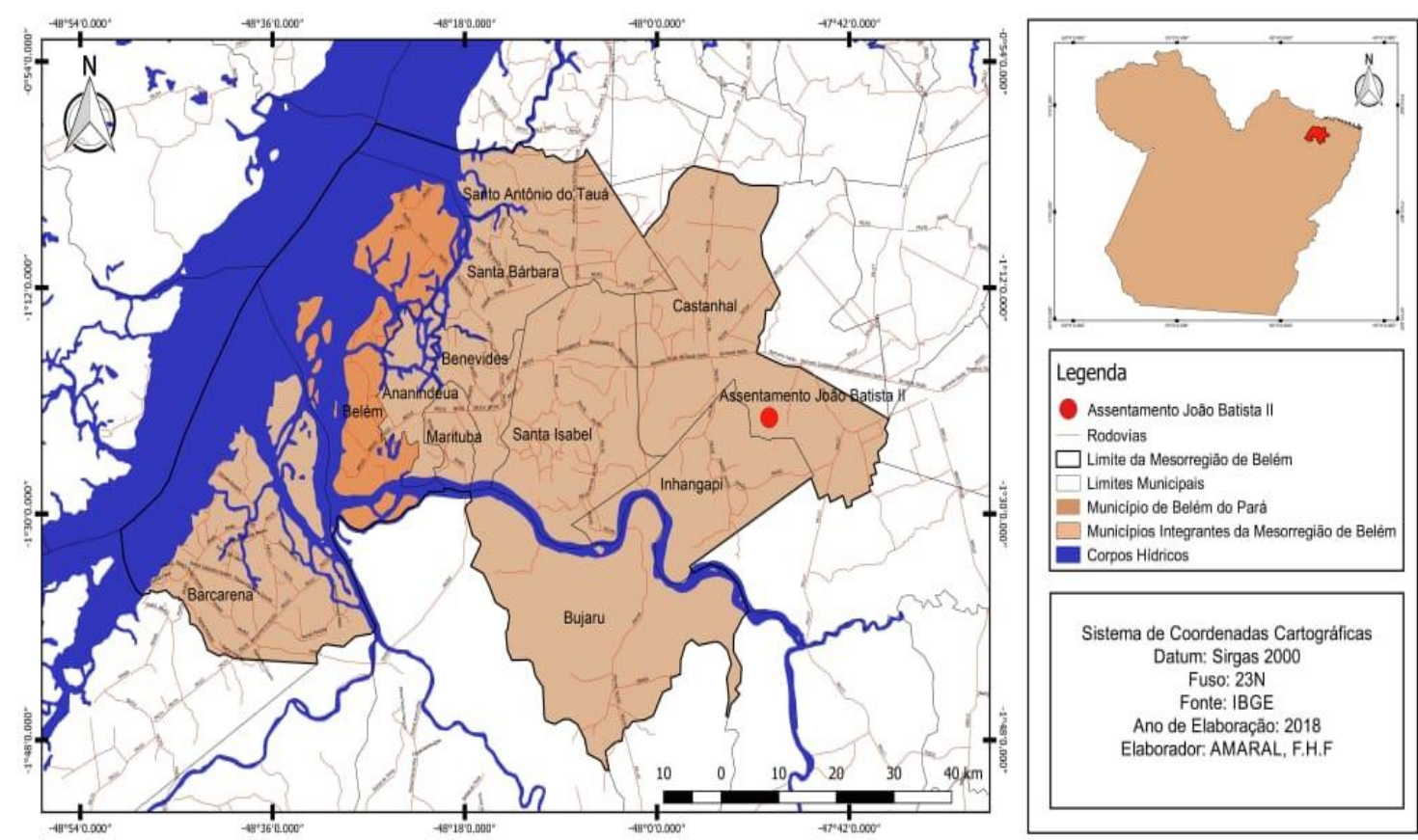

Fonte: IBGE/ ITERPA, 2005.

Como mencionou uma liderança, "era necessário ter um assentamento perto da capital (Belém), o movimento estava se fortalecendo no Sudeste do Pará, mas era preciso um assentamento mais próximo" (Entrevistado B. 2011). Nesse sentido, a formação do Assentamento João Batista II, está relacionada a duas demandas do movimento, são elas: a localização próximo de Belém $(75,6 \mathrm{Km})$ e a formação de uma "frente de massas" para contribuir em outras mobilizações. Conforme menciona Fernandes (2000, p. 281) "a ocupação é um processo socioespacial e político que precisa ser entendido como forma de luta popular de resistência do campesinato, para sua recriação e criação".

Os trabalhos de base se concentraram nas cidades de Castanhal e Ananindeua, ambas recebendo acampamentos. Durante essas ações, as famílias foram cadastradas e participavam de reuniões semanais. Nas reuniões, os sem-terra foram familiarizados com a dinâmica do movimento, suas regras de disciplina e organização política, tendo em vista que a luta pela terra é colocada como um meio para alcançar melhorias nas condições de vida desses trabalhadores. Conforme aponta uma das lideranças do movimento, o sentido do trabalho de base é "convencer o trabalhador a lutar: não prometemos terra! Alguns dizem que o MST da terra. Na verdade, só se consegue terra na luta, por isso a ocupação" (Entrevistado K. em 2011). 
A fala de outro assentado "B" elucida bem a inserção dos sem-terra, na dinâmica dos acampamentos, marchas e ações que deram origem ao Assentamento João Batista II:

\begin{abstract}
Nós acampamos lá no Abacatal no Aurá (Ananindeua). O ônibus chegou, "apanhou" os cadastrados, e nós fomos lá pro Abacatal. Acampamos dia 22 de agosto, quando foi dia 3 de setembro, nós saímos em fileira, em direção à Belém. Aqui em Castanhal, já tinha um grupo. Foi feito o trabalho de base, e nos encontramos lá na praça da matriz. Ai reuniu os dois acampamentos. [...] acampamos na Praça da Bíblia, no Entroncamento. Quando foi dia 7 de setembro, fomos para a praça da leitura, em São Braz. De lá nós saímos de pés, rumo a Praça da República. Foi meu primeiro "grito dos excluídos". Como tinha o desfile das forças armadas nós fomos impedidos de chegar lá [...] montamos acampamento na Praça da República. Depois ocupamos o INCRA (sede Belém). Passamos lá 15 dias. [...] Do INCRA voltamos para o Aurá de novo, aí passamos 30 dias (entrevista concedida por B. em 2012).
\end{abstract}

O relato indica as condições em que ocorre o engajamento político do assentado.

Segundo os militantes do MST entrevistados, as caminhadas, acampamentos e ocupações, são espaços de aprendizagem coletiva onde o sentido da luta pela terra ganha vida e o sujeito forma-se no entendimento da dimensão social da terra e da importância da reforma agrária, constituindo-se como parte de um projeto territorial (a luta pelo acampamento) e um sujeito coletivo (o Sem-Terra). A disciplina do movimento também é apresentada, como demonstrou um dos sujeitos ao afirmar que:

Fizemos um acampamento provisório pra gente fazer a formação de futuros assentados. Que a ideia, nossa, enquanto MST é fazer o acampamento, formar os grupos de famílias, de dez até vinte famílias por grupo. Aí fazer formação, a forma de comportamento, respeito, a questão do preconceito, então tudo isso a gente trabalhava pra, digamos... é uma forma do pessoal se preparar, para quando chegar na terra, ter respeito um com o outro. (Entrevista concedida por L. em 2012).

Neste sentido, os acampamentos são espaços de formação política e socialização de experiências de luta pela terra, tendo como base a construção horizontal dos acordos de convivência no assentamento, a partir de assembleias que passam a definir questões como: horários de entrada e saída, problemas de furtos e agressões e formação dos grupos de trabalho, entre outras questões. Esses processos não são isentos de contradições, fato que dificulta a criação de um grupo coeso e homogêneo, pois nos assentamentos diversas trajetórias sociais se encontram e passam a conviver dividindo uma mesma área.

No acampamento João Batista II foram alojadas inicialmente 830 famílias em uma fazenda cuja área comportava somente 157 (1.761,76 ha). Devido a grande concentração 
fundiária, a quantidade de famílias que buscam uma terra para trabalhar é gigantesco, o que gera gigantescas mobilizações que garantem a ocupação.

O primeiro período analisado (1998-2001) é marcado pela precariedade nas condições de instalação das famílias, falta de recursos, fome e dificuldades de coesão dos sujeitos na definição do projeto coletivo. Tais aspectos são comuns aos acampamentos, como destaca Zeneratti (2014, p. 139):

\footnotetext{
O acampamento é um momento transitório para se chegar ao assentamento, normalmente caracterizado por privações de toda ordem, como condições inadequadas de moradia, alimentação, saneamento, educação, segurança, enfim ingredientes indispensáveis à dignidade humana e resguardados constitucionalmente a toda pessoa humana.
}

Nos primeiros anos da ocupação, as famílias dependiam de doações e das cestas básicas fornecidas pelo Instituto Nacional de Colonização e Reforma Agrária (INCRA), o que lhes garantia apenas os alimentos básicos para se manterem. As atividades produtivas iniciais foram os ciclos rápidos, lavouras brancas e criação de animais de pequeno porte, com a finalidade básica do autoconsumo, pois, nesse período, os suejeitos não puderam contar com financiamentos e assistência técnica.

As famílias, descapitalizadas, produziam individualmente e somente para sobrevivência, porém, também nessa fase, se iniciam as discussões sobre o trabalho coletivo, que foi adotado posteriormente pelos núcleos.

Nesse primeiro momento, onde o pasto dá lugar as roças e as barracas de lona preta, uma nova dinâmica de ocupação do território é empreendida, trata-se de ações que objetivam efetivar a territorialização camponesa que, conforme escreve Fernandes (2008), se fortalece por meio da luta pela terra e pelas políticas de reforma agrária. O acampamento é, portanto, um importante passo na construção do território camponês. Na Figura 2, a vista parcial do acampamento que deu origem ao Assentamento João Batista II, além das precárias habitações de lona verifica-se a queima do capim necessária a preparação do solo para os primeiros plantios. 
Figura 2: Parte da ocupação que deu origem ao Assentamento João Batista II, com barracas cobertas com lona preta

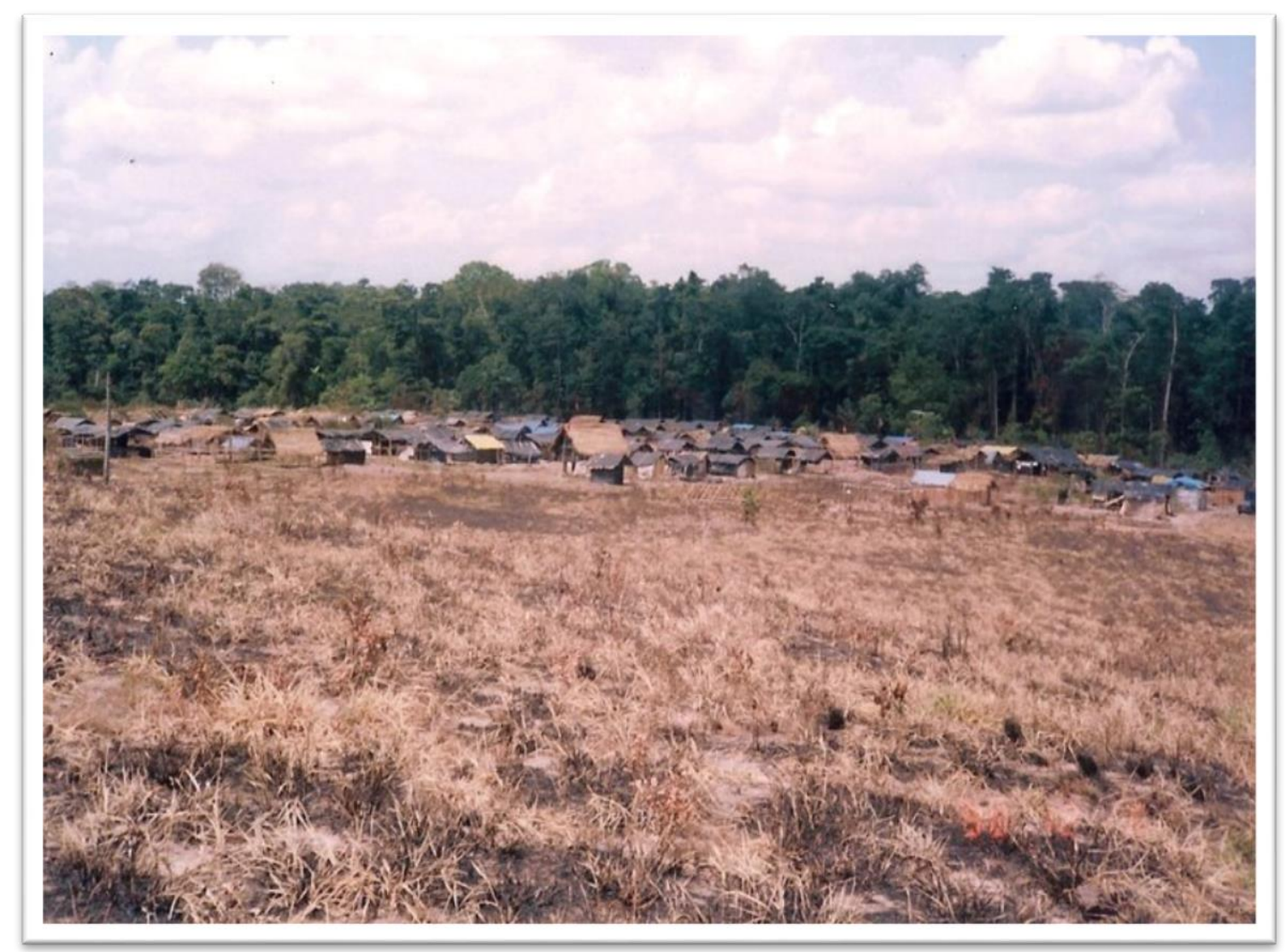

Fonte: acervo pessoal de Márcio Costa, 1998.

$\mathrm{Na}$ fase de ocupação o trabalho foi organizado primeiramente de forma individualizada em pequenas áreas de 0,3 a 0,6 hectares, com o uso de mão de obra predominantemente familiar. Como os primeiros plantios ainda não davam conta de alimentar as famílias, as cestas básicas, doadas pelo INCRA, eram fundamentais. Basicamente, nesse primeiro período as fontes de alimento e sustento das famílias acampadas eram: extrativismo vegetal (Açaí, Castanha do Pará) e animal (caça e pesca), doações de alimentos coletados na cidade de Castanhal e fornecidos pelo Estado, produção agrícola em pequenas áreas e nos quintais, trabalho temporário (alguns membros da família) e ajuda externa de familiares fora do acampamento. Como menciona o entrevistado L a alimentação é um dos elementos centrais nesse contexto de acampamento:

[...] tirava uma comissão pra sair em redes de supermercado, armazém, pedindo doação pra nós... Ou liberava pra trabalhar. Ia uns três, quatro do grupo de família pra trabalhar e trazer alguma coisa pra cá, tinha esse negócio, 
enquanto não vinha a cesta básica. Ai, quando veio a cesta básica não melhorou tanto, porque nessa época, vinha só o feijão o óleo, o milho e o arroz, era o básico que vinha. E agora como é que ia fazer o café? O "pedaço" (Carne), que não vinha. (Entrevista concedida por L., em 2011).

Quando as cestas básicas chegavam uma equipe ficava responsável pela distribuição dos alimentos. Como o número de pessoas por família variava, os mantimentos eram distribuídos segundo a necessidade das famílias. Na Figura 3 os trabalhadores descarregando um caminhão com alimentos doados pelo INCRA, em dezembro de 1998.

Figura 3: Trabalhadores descarregando o caminhão de alimentos

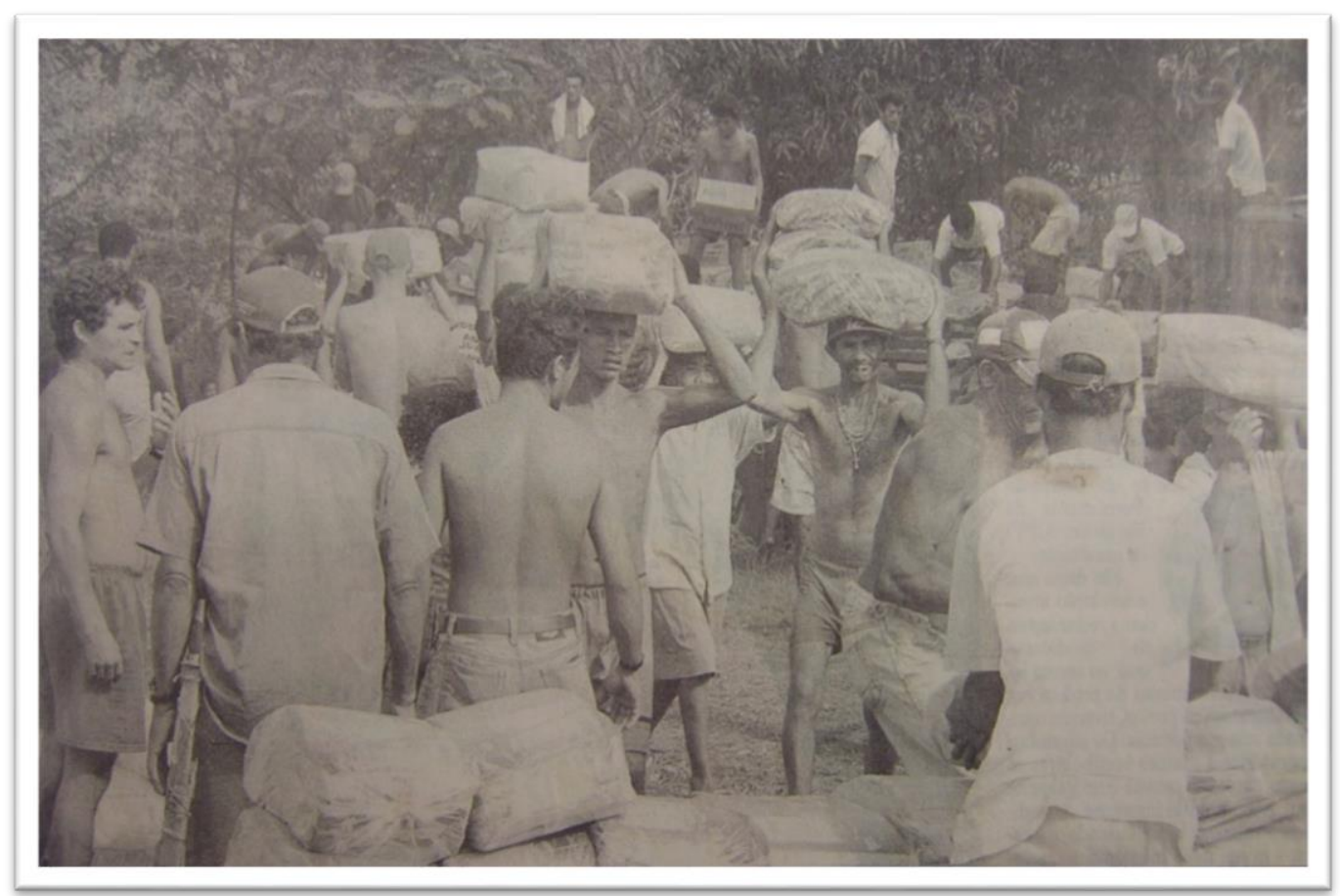

Fonte: Jornal liberal, 1998.

A dinâmica territorial do acampamento foi marcada pela pequena produção agrícola, predomínio do trabalho individual, com algumas iniciativas no sentido de fortalecer a produção coletiva, famílias descapitalizadas e forte dependência em relação à doação de alimentos, processo que se mantem até a formalização do Assentamento. $\mathrm{O}$ Quadro 1 apresenta uma síntese dessa dinâmica no contexto do acampamento. 
Quadro 1: Síntese da dinâmica territorial no acampamento João Batista II

\begin{tabular}{|c|c|c|c|c|}
\hline Período & Produção & $\begin{array}{c}\text { Formas de } \\
\text { organização } \\
\text { do trabalho }\end{array}$ & Dinâmica Socioprodutiva & $\begin{array}{c}\text { Número } \\
\text { de } \\
\text { famílias }\end{array}$ \\
\hline $\begin{array}{l}(1998- \\
2001)\end{array}$ & $\begin{array}{l}\text { Realizada em } \\
\text { pequenas áreas } \\
\text { (roças individuais); } \\
\text { Produção ligada a } \\
\text { subsistência, com } \\
\text { produtos como: } \\
\text { macaxeira, maxixe, } \\
\text { frutas; } \\
\text { Criação de alguns } \\
\text { animais (aves e } \\
\text { suínos) e, de forma } \\
\text { não representativa, } \\
\text { o gado. }\end{array}$ & $\begin{array}{l}\text { Individual; } \\
\text { Iniciativas } \\
\text { para } \\
\text { organizar o } \\
\text { trabalho na } \\
\text { forma } \\
\text { coletiva e } \\
\text { criação dos } \\
\text { núcleos de } \\
\text { produção; } \\
\text { Realização de } \\
\text { mutirões no } \\
\text { próprio } \\
\text { núcleo e entre } \\
\text { os núcleos de } \\
\text { produção. }\end{array}$ & $\begin{array}{l}\text { Substituição gradativa do } \\
\text { pasto pela produção } \\
\text { diversificada; } \\
\text { Produção restrita a uma } \\
\text { pequena área de } 0,3 \text { a } 0,6 \text { ha; } \\
\text { Necessidade de cestas básicas } \\
\text { fornecidas pelo INCRA; } \\
\text { Alimentação complementada } \\
\text { com doações, extrativismo e } \\
\text { pesca; } \\
\text { Famílias descapitalizadas. } \\
\text { Dezembro de } 2000 \text { o } \\
\text { assentamento é oficialmente } \\
\text { criado. }\end{array}$ & 830 \\
\hline
\end{tabular}

Fonte: Guilherme Júnior, 2018.

Com base nos dados e informações levantadas, a territorialização dos acampados é marcada pela precariedade, dada a dificuldade de produzir e, portanto, permanecer na terra. O uso do território também esteve restrito, já que as famílias descapitalizadas tiveram que contar com produtos do extrativismo, ou mesmo, levantar recursos com o trabalho temporário em outras propriedades e a ajuda de parentes. Sobreviver na terra é o primeiro desafio encontrado pelos acampados. Sendo assim, a luta camponesa não se restringe a conquista de um pedaço de terra, vai além exigindo a criação de um ambiente social de autonomia produtiva e de organização social.

b) O Assentamento João Batista II e a organização socioprodutiva (2001-2005)

Conforme descreve Cardoso (2001) em 4 de maio de 1999 o Diário Oficial da União publica a desapropriação da fazenda Tanarí, sendo que somente em outubro os assentados recebem o edital de posse. Através da Portaria $\mathrm{N}^{\circ}$ 95, de 18 de dezembro de 2000, a fazenda Tanarí passou a se chamar "Projeto de Assentamento João Batista II". Com a regularização da terra somente 157 famílias são assentadas, ficando divididas em núcleos de produção. 
O recorte temporal (2001-2005) busca apreender uma fase em que ocorreu a consolidação dos primeiros projetos agropecuários no assentamento, as formas de organização do trabalho e algumas contradições que permearam esse processo. Os assentados estavam divididos em 19 núcleos de produção e o trabalho era, majoritariamente, organizado na forma semicoletiva e coletiva. Nesse contexto, já existiam 13 famílias que optaram por produzir individualmente, e seus lotes estavam localizados nos arredores dos projetos coletivos. Nessa fase foram adquiridos os primeiros financiamentos de "fomento" e "habitação" (comum a todos os assentados) e o PRONAF-A destinado somente aos membros da Associação dos Produtores Rurais do Assentamento João Batista II (APROCJOB), que restringiu os investimentos a forma coletiva.

De acordo com Cardoso (2001), 144 famílias receberam créditos de fomento e habitação, sendo que parte desse crédito foi investido no sistema de produção coletivo, com a compra de um trator e implementos. Com a liberação do PRONAF-A os beneficiários optaram por investir em três linhas de produção, sendo elas: a lavoura branca, gado leiteiro e de corte e o açaí. Os projetos propostos baseavam-se nas potencialidades produtivas e no acesso ao mercado, identificadas no Projeto de Desenvolvimento do Assentamento (PDA). O objetivo era garantir alimentos às famílias, além de fomentar produtos ligados à comercialização, no caso o leite e o açaí.

As três linhas de produção (lavoura branca, gado e açaí) objetivavam estruturar economicamente o assentamento, e, neste sentido, optou-se pela lavoura branca, com culturas voltadas o autoconsumo, tais como: feijão, milho, arroz, macaxeira além de culturas perenes, a exemplo da banana e do mamão. A segunda linha de produção foi o açaí, com o sistema de irrigação, já que as mudas foram plantadas em terra firme. Os assentados chamam esse tipo de cultura de "açaí no seco". Cada núcleo escolheu uma área, preparou as covas e fez a adubação. Neste sistema também estava previsto a construção de infraestruturas para viabilizar a produção, desse modo, foram adquiridas para os núcleos: tubulação, estrutura para caixa d' água, bombas e poços artesianos.

Os projetos não obtiveram êxito por carência de infraestrutura, principalmente a ausência de energia elétrica nos lotes, assistência técnica insatisfatória, desconhecimento com atividade agrícola e pecuária, bem como, dificuldades na gestão dos recursos. Como menciona os entrevistados: 
Todos os núcleos construíram a estrutura para caixa d'água, toda a tubulação, bomba, e pediu para a empresa cavar o poço, tudo isso teve um custo. E se plantou o açaí, quatro anos depois com o "governo Lula", é que foi a energia pros lotes. Moral da história? A maioria dos núcleos já tinha perdido seu açaí (entrevista concedida por N., em 2011).

Nesse projeto que saiu para um grupo de pessoas...meu projeto deu cinquenta e pouco mil, para nosso núcleo. Acho que saiu dezoito gado, a menor parte foi pro gado, o resto, foi investido em muda de açaí, caixa de água, poço artesiano, monte de mangueira pra irrigar o açaí, sem ter um fiapo de luz em canto nenhum, e foi empurrando e bomba, pra puxar água do poço, não sei como, se não tinha energia! Fizeram uma estrutura! Ai acabaram tudo, o que ficou foi esse gadinho pra dividir entre oito pessoas, deu pra cada pessoa uma vaca e uma banda, pra cada um (entrevista concedida por A., em 2011).

Nós tivemos muito prejuízo, por que enfim, marinheiro de primeira viagem e faltou orientação. Assistência técnica. Foi liberado o projeto, o técnico assinou o projeto, mas a contratação veio uns seis meses depois. Na hora do implante faltou, isso aí, a orientação técnica. O pessoal conta que teve muita gente que foi plantar o açaí, e não tirou nem do saquinho (risos) deveria ter a assistência técnica orientando, mas mesmo assim é gente cabeça dura (entrevista concedida por L., em 2011).

Muita gente acabou com o gado todinho, por que tinha gente que queria trabalhar com o gado, conhecia o gado na panela só! O gado vinha o pessoal já tava correndo de medo. Alguns acharam melhor vender, que não eram acostumados a trabalhar, e perderam e ficaram só com as dívidas. O assentamento, hoje, de modo geral, não digo cem por cento, mas noventa e cinco por cento, o pessoal hoje tá em debito. Por que faltou esse acompanhamento. (Entrevista concedida por L., em 2011).

No caso do açaí, os aspectos centrais que dificultaram o processo foram: a falta de apoio técnico, dificuldade de insumos e a falta de energia elétrica nos lotes, já que se tratava de açaí irrigado, necessitando das bombas elétricas. Com os prejuízos nos projetos, muitos assentados propuseram vender o gado para quitar suas dívidas e garantir o sustento da família. Portanto, os projetos foram marcados por desajustes na sua implementação e gerenciamento, o que ocasionou a perda dos bens adquiridos no financiamento público do PRONAF-A.

Outro aspecto que cabe menção é a organização produtiva do assentamento. Araújo (2005) comparou os modelos de organização no interior do Assentamento João Batista II, tomando como recorte temporal os anos de 1998-2004. A autora constatou alguns aspectos importantes relacionados aos sistemas coletivos e semicoletivo.

Conforme descreveu, os modelos semicoletivo e coletivo tiveram: a) maior acesso ao crédito agrícola; b) assistência técnica; c) área plantada; d) rebanho bovino e; e) auferiram maior rentabilidade se comparados ao modelo de gestão individual. O MST, na direção política do assentamento, incentivou majoritariamente projetos coletivos, fato que 
justificou a hegemonia do número de famílias e área ocupada por essas formas de organização da produção até 2005. O gráfico-1 compara a área em hectares e o número de famílias envolvidas.

Gráfico 1: Área e Número de famílias nos sistemas: coletivo, semicoletivo e individual, no Assentamento João Batista II

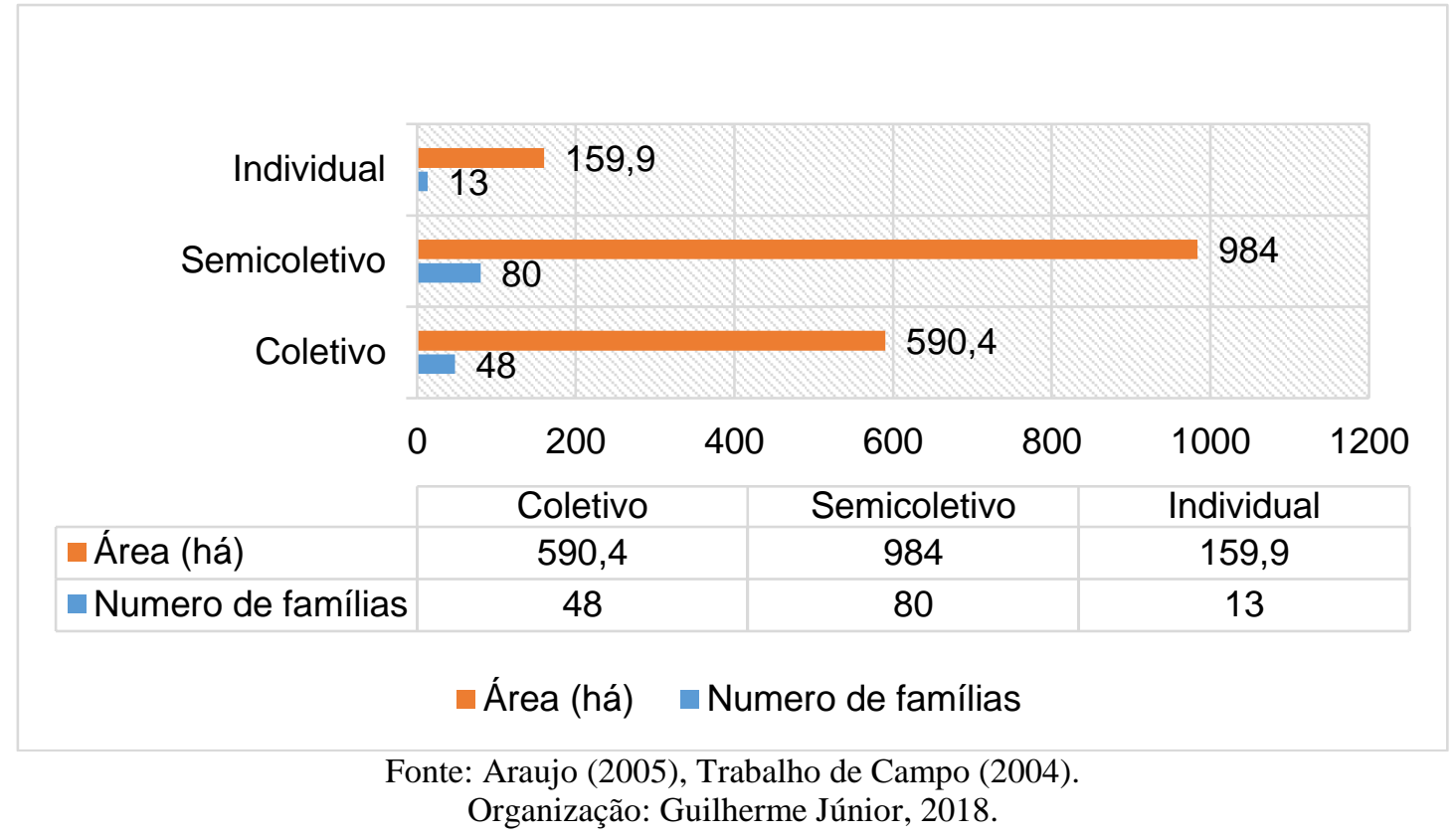

Ainda conforme Araújo (2005), a predominância do trabalho na forma semicoletiva já é indicativa que a proposta do MST deveria se adequar a realidade dos assentados. Estes ainda que trabalhassem em áreas coletivas, não abriram mão de sua produção individual. Essa adequação a proposição do movimento foi marcada por dificuldades de adaptação das famílias a esse modelo.

Dos contratempos relacionados à organização do trabalho, destacam-se dois: i) a forma de inserção do trabalho feminino nas áreas de produção e; ii) a participação dos assentados no regime de trabalho coletivo. Esses dois aspectos evidenciam a tentativa, por parte do MST, de homogeneizar as formas de produzir impondo o modelo coletivo como perspectiva para o desenvolvimento do assentamento, nesse aspecto Fabrini (2002, p.82), destaca que:

A população dos assentamentos apresenta enorme diversidade que o termo assentado não revela. A generalização não permite reconhecer as diferenças existentes no interior desta "categoria". A diversidade de identidade social apresenta-se unificada na subordinação e reunida espacialmente na ocupação da terra. 
O trabalho feminino na roça encontrou dificuldades, sobretudo pelo fato de o trabalho ser basicamente manual e exigir grande esforço físico. Nas falas abaixo, as impressões de dois assentados (um homem e uma mulher), sobre a realização do trabalho feminino:

No (trabalho) coletivo ficou um período assim de uns cinco anos... O trabalho coletivo é bom, mas quando não se entende não consegui avançar. A gente começou com o trabalho, aí todo mundo trabalhava igual, eu capinava, mulher, todo mundo tinha que trabalhar igual, pra dizer que contou o dia, que contou o trabalho. Tipo um trabalho escravo. Eu sei que trabalho coletivo é bom, mas não pra ficar daquele jeito aquela força de trabalho igual homem e mulher. Eu, na minha concepção, eu acho que isso não é certo, tem que ser melhor dividido os trabalhos, não sei... Sei que era muito sacrifício. A gente tinha que competir com a força do homem, se o homem fizesse meia tarefa de capina, a gente tinha que fazer meia tarefa também. Eu capinei muito, esse capinzão alto arrancava igual. (Entrevista concedida por A., em 2011).

Nós fazíamos de primeiro no "enxadão", tirava o "baquiarão" aí, multidão de gente! Virando capim na enxada. Quando dava onze horas da manhã, tinha mulher que dava até agonia, dava "vertigem", caía, todo mundo trabalhava, criança, jovem, arrastando capim na hora que não estavam estudando, estavam lá carregando capim na cabeça, jogando pros aterros. Uma luta assim que não é pra todo mundo. (Entrevista concedida por M., em 2011).

Nos discursos dos entrevistados, podemos identificar o quão difícil era a realização do trabalho nesse sistema, a necessidade de equiparação produtiva das forças de trabalho feminina e masculina, colocava-se como uma regra de inserção social. Neste sentido, longe de demonstrar uma inaptidão ou fragilidade deste seguimento, evidenciase a exposição da mulher a um trabalho extremamente exaustivo, cuja realização ocorre tanto na "roça" quanto na "casa".

Além das contradições percebidas na inserção do trabalho feminino, a adequação, de modo geral, dos membros do assentamento ao trabalho coletivo se mostrou uma dificuldade, sobretudo no que diz respeito à disciplina no cumprimento e assiduidade dos participantes dos núcleos, pois as ausências geravam conflitos internos, fato que posteriormente enfraqueceu a própria manutenção do trabalho no sistema coletivo, como relata o entrevistado abaixo, que é ex-presidente de um núcleo de produção:

Começamos trabalhar assim. É bom! Mas... Se na verdade todos tivessem os mesmo objetivos, o mesmo rumo de crescer junto seria melhor. Porque trabalhava-se coletivamente tudo se produzia. Tirava-se o capital, o capital de giro pra tornar a comprar semente, "aradar", etc. O lucro é dividido entre as famílias, nós vivíamos do lucro. Sempre deixando uns dez por cento, vinte por cento, pra ir aumentando a produtividade. Mas chega um momento que... Pra você ver, que nem os dedos da mão é igual, o cara se "dana" a adoecer, outro 
vai ali na rua não vem (trabalhar) e começa a ficar dois, três trabalhando e enrola tudo e a produção vai caindo, mas na hora de dividir, tem que ser entre todos, cê ta entendendo como é que é? Chega uma situação, que o "cabra" fica sozinho, pelejando, trabalhando e o pessoal, no meio do mundo né? (Entrevista concedida por M., em 2011).

A ausência de alguns assentados revela a dificuldade de seguir o sistema coletivo, o que gerava conflitos, principalmente no momento da partilha dos rendimentos da produção. Quem não ia trabalhar, deveria pagar pela falta, todavia, alguns assentados não aceitavam e as desavenças ocorriam. Com o trabalho sendo realizado por poucos, a capacidade produtiva do núcleo foi diminuindo, e, por conseguinte, os rendimentos também.

A ocupação, como informa-nos Fabrini (2011), é uma etapa do processo de territorialização camponesa marcada, em grande medida, por incertezas, ainda que já exista o componente territorial, conforme ressalta "assentar na terra é dominar, controlar e ter poder sobre o espaço, o que conforma o território" (FABRINI, 2011, p. 103).

No Quadro 2 apresentamos uma nova síntese, baseada no período de 2001 a 2005, onde se tem uma mudança nas formas de organização do trabalho e na dinâmica socioprodutiva.

Quadro 2 - Síntese da dinâmica territorial no Assentamento João Batista II (2001-2005)

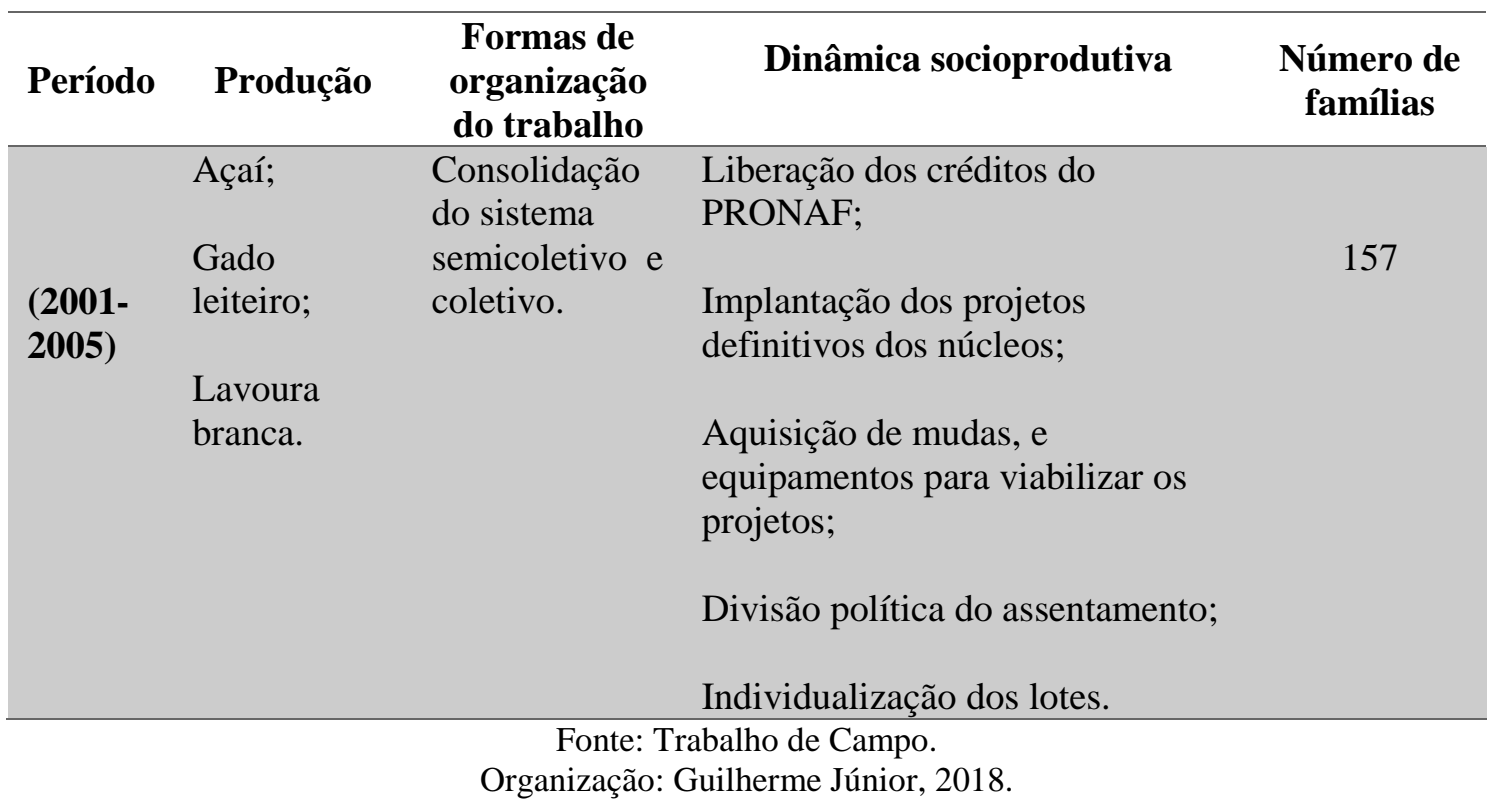

c) O Assentamento João Batista II e a organização socioprodutiva (2005-2012) 
Esse período que abrange os anos de 2005-2012 é fortemente é marcado pela fragmentação política no interior do assentamento, tendo rebatimentos na situação econômica apresentada a época da finalização da pesquisa.

No ano de 2005 um episódio abalou a organização dos assentados, dividindo-os politicamente. Alguns integrantes da direção do movimento foram expulsos sobre a acusação de desvios de recursos, conforme menciona dois entrevistados.

O "racha" aconteceu em 2005, tinha alguns projetos, o convênio da João Batista que era para pagamento da assistência técnica, para o desenvolvimento do projeto de recuperação do assentamento, alguns recursos que a gente começou a perceber que não estavam sendo implantados, então tava tendo algum desvio (entrevista concedida por M. em 2012).

Depois houve aquela fraqueza entre a coordenação dos assentados, e a população se reuniu, e chamou a direção estadual, direção nacional. Acabou que a gente expulsou 7 companheiros, de frente da militância. Expulsamos eles do movimento (MST), mas achamos que eles estavam conosco na conquista da terra, e eles permanecem com o lote deles. Eles entraram pra FETRAF, e continuou o MST. O MST, teve um grupo que permaneceu na cooperativa e um outro grupo que fundou uma outra associação. O INCRA se aproveitou desse momento de desarticulação, desmobilização do assentamento, eles vieram e falaram. Não, agora a terra não é mais por núcleo. E vieram com agrimensores e dividiram um lote para cada assentado. Ai é que houve um caos. (Entrevista concedida por N. em 2012).

Como aludido nas falas, os integrantes expulsos criam outra associação que passou a polarizar politicamente o assentamento e, a partir de então, um clima de rivalidade entre as organizações se estabeleceu, o que enfraqueceu ambas. Tal fato gerou a criação, em 2007, de uma terceira entidade de representação vinculada a um grupo dentro do MST, como mostra o quadro 3:

Quadro 3: Síntese de informações sobre as entidades do Assentamento João Batista II

\begin{tabular}{llll}
\hline & $\begin{array}{l}\text { Associação dos } \\
\text { Produtores } \\
\text { Rurais do } \\
\text { Assentamento } \\
\text { João Batista II }\end{array}$ & $\begin{array}{l}\text { Associação } \\
\text { Comunitária do } \\
\text { assentamento } \\
\text { João Batista II }\end{array}$ & $\begin{array}{l}\text { Cooperativa dos Pequenos } \\
\text { Agricultores de } \\
\text { Comercialização e } \\
\text { Industrialização do } \\
\text { Nordeste do Pará } \\
\text { COOPAP }\end{array}$ \\
\hline Sigla & APROCJOB & ACAJOB & 2007 \\
\hline Ano de criação & 2000 & 2005 & MST \\
\hline $\begin{array}{l}\text { Movimento social } \\
\text { envolvido }\end{array}$ & MST & FETRAF & 114 \\
\hline $\begin{array}{l}\text { Número de } \\
\text { associados }\end{array}$ & 20 & 54 & \\
\hline
\end{tabular}

Fonte: Guilherme Junior, 2012. 
Deste ponto, as relações políticas no assentamento foram marcadas pela fragmentação, intensificadas pela ação das entidades de representação (associações e cooperativa). Os projetos passaram a ser disputados entre as entidades e a cooperação entre as famílias se enfraqueceu. A crise de representatividade e a fragmentação política geraram a intensificação de conflitos e o enfraquecimento das entidades que não tem conseguido superar suas diferenças e equacionar os problemas da comunidade. A terra foi individualizada pelo INCRA e os projetos coletivos e semicoletivos foram completamente abandonados, mostrando que o desenvolvimento é um processo contraditório e histórico, marcado pela conflitualidade que pode gerar uma nova dinâmica de desenvolvimento, como no caso da conflitualidade que gerou a ocupação da terra e a possibilidade de criação do projeto de assentamento, ou impor sérios constrangimentos à política de desenvolvimento, como na etapa em questão.

Nesse sentido, a dinâmica territorial até o momento da pesquisa tinha a seguinte configuração, conforme o Quadro 4.

Quadro 4: Síntese da dinâmica territorial no Assentamento João Batista II

\begin{tabular}{lllll} 
Período & Produção & $\begin{array}{c}\text { Formas de } \\
\text { organização } \\
\text { do trabalho }\end{array}$ & Dinâmica socioprodutiva & $\begin{array}{l}\text { Número de } \\
\text { famílias }\end{array}$ \\
\hline & Açaí; & Individual & $\begin{array}{l}\text { Produção marcada por } \\
\text { iniciativas individuais; }\end{array}$ & \\
\hline $\mathbf{2 0 0 5}-$ & Farinha; & Leite; & $\begin{array}{l}\text { Baixo grau de cooperação entre } \\
\text { os assentados; }\end{array}$ & 157 \\
& Lavoura branca. & $\begin{array}{l}\text { Fragmentação políticas: presença } \\
\text { de três organizações disputando } \\
\text { o poder no assentamento. }\end{array}$ & \\
\hline
\end{tabular}

Fonte: Guilherme Junior, 2018.

Além da produção, a comercialização dos produtos advindos do assentamento também foi impactada pela nova conjuntura política e também passou a ser feita de maneira individualizada, o que significou um retrocesso em relação ao que se tinha anteriormente. Os produtos passaram a ser transportados no interior de um ônibus juntamente com as pessoas, sendo oferecidos à venta na feira central de Castanhal.

A comercialização da produção no Assentamento João Batista II, tem se caracterizado pela grande dificuldade de inserção no mercado, além dos baixos preços 
dos produtos. Os atravessadores que compram os produtos determinam os preços, lucrando com a revenda para as feiras locais ou redes de supermercado.

A fragmentação política que ocorreu a partir de 2005, com o "racha" no interior do assentamento, teve rebatimentos na organização socioprodutiva posterior até 2012. O fracasso nos projetos e o enfraquecimento na representatividade contribuíram para que, a produção se restringisse a um número pequeno de famílias (15), a partir de iniciativas individuais. $\mathrm{O}$ aluguel de pasto aponta para uma forma de exploração econômica que não condiz com a proposta de Reforma agrária e desenvolvimento rural. Até o momento pesquisado as formas de organização da produção não deram conta de criar um território de autonomia e reprodução dos camponeses. A superação dos conflitos internos entre as entidades de representação mostra-se como uma necessidade para potencializar o desenvolvimento na área do Assentamento João Batista II.

d) O Assentamento João Batista II: uma breve atualização dos dados (Janeiro de 2019)

Em visita realizada em janeiro de 2019 foi possível observar algumas mudanças e permanências nos processos e nas formas presentes no assentamento. Em primeiro lugar a precariedade no acesso ao assentamento permanece, já que a estrada que liga a comunidade ao centro de Castanhal, não possui capeamento asfáltico e, nesse período (janeiro) de chuvas intensas na Amazônia, o transito de veículos fica extremamente prejudicado. Em termos de infraestrutura a principal mudança percebida foi a construção de uma Unidade Básica de Saúde, que segundo informações foi inaugurada em junho de 2016, na figura-4 um comparativo do local de como era e como está atualmente. 
Figura 4: Caixa de água do Assentamento e a Unidade Básica de Saúde, José Rufino dos

Santo

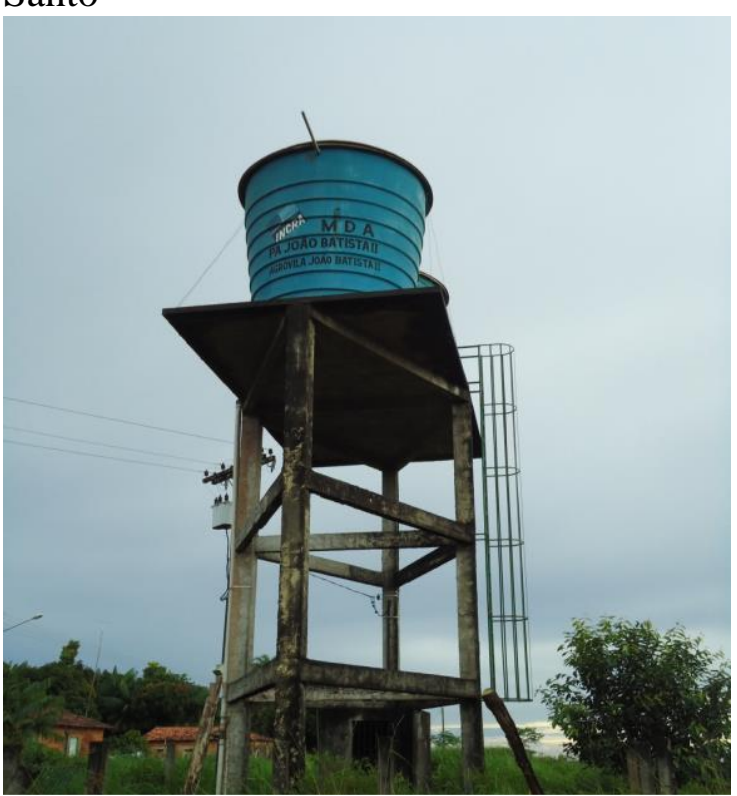

Fonte: Guilherme Junior, 2012

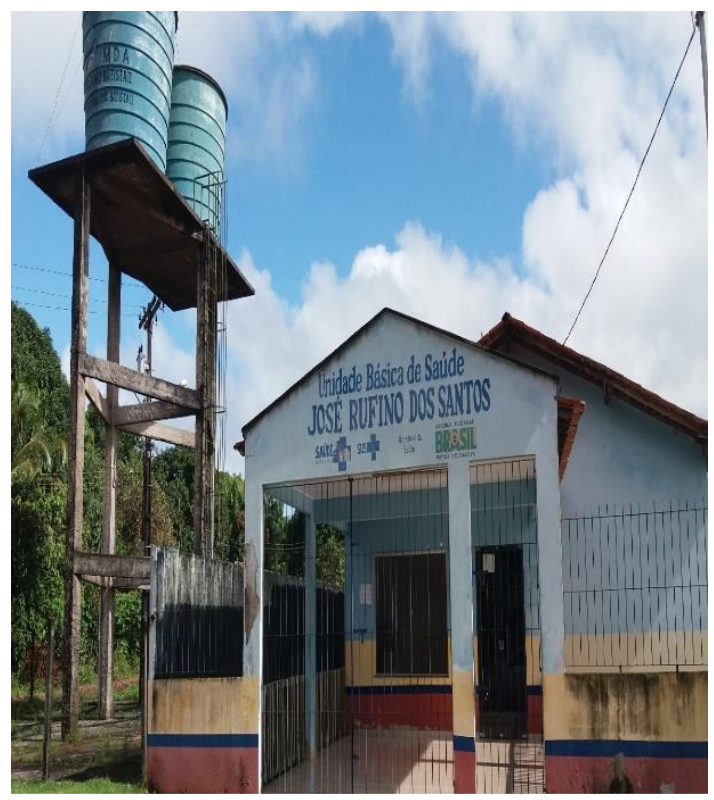

Fonte: Guilherme Junior, 2019.

No que diz respeito a produção o número de famílias com algum cultivo nos lotes aumentou de quinze, de acordo com os dados levantados em 2012, para trinta e cinco em 2019. Atualmente existe somente uma associação a ACAJOB (ligada a FETRAF) atuando junto aos assentados. A COOPAP, cooperativa que foi criada em 2007, depois do referido "racha" no MST, deixou de atuar no assentamento, por razões que os entrevistados não souberam dizer. O MST tem organizado atualmente um coletivo de agricultores que reúne entorno de 15 famílias em um projeto que propõe uma transição agroecológica. A iniciativa intitulada de SAPO (Sistema Agroecológico de Produção orgânica), busca fomentar práticas agroecológicas no assentamento e entre comunidades rurais vizinhas, entre as ações estão: a socialização de conhecimentos entre os agricultores sobre produção orgânica, parcerias com instituições como universidades e centros de pesquisa, cultivo de mudas, produção com o mínimo de corte e queima, compostagem além de cobertura verde na adubação do solo. Na figura-5 a bandeira do coletivo e uma parte do viveiro de mudas de açaí. 
Figura 5: Bandeira do SAPO e viveiro de mudas de açaí

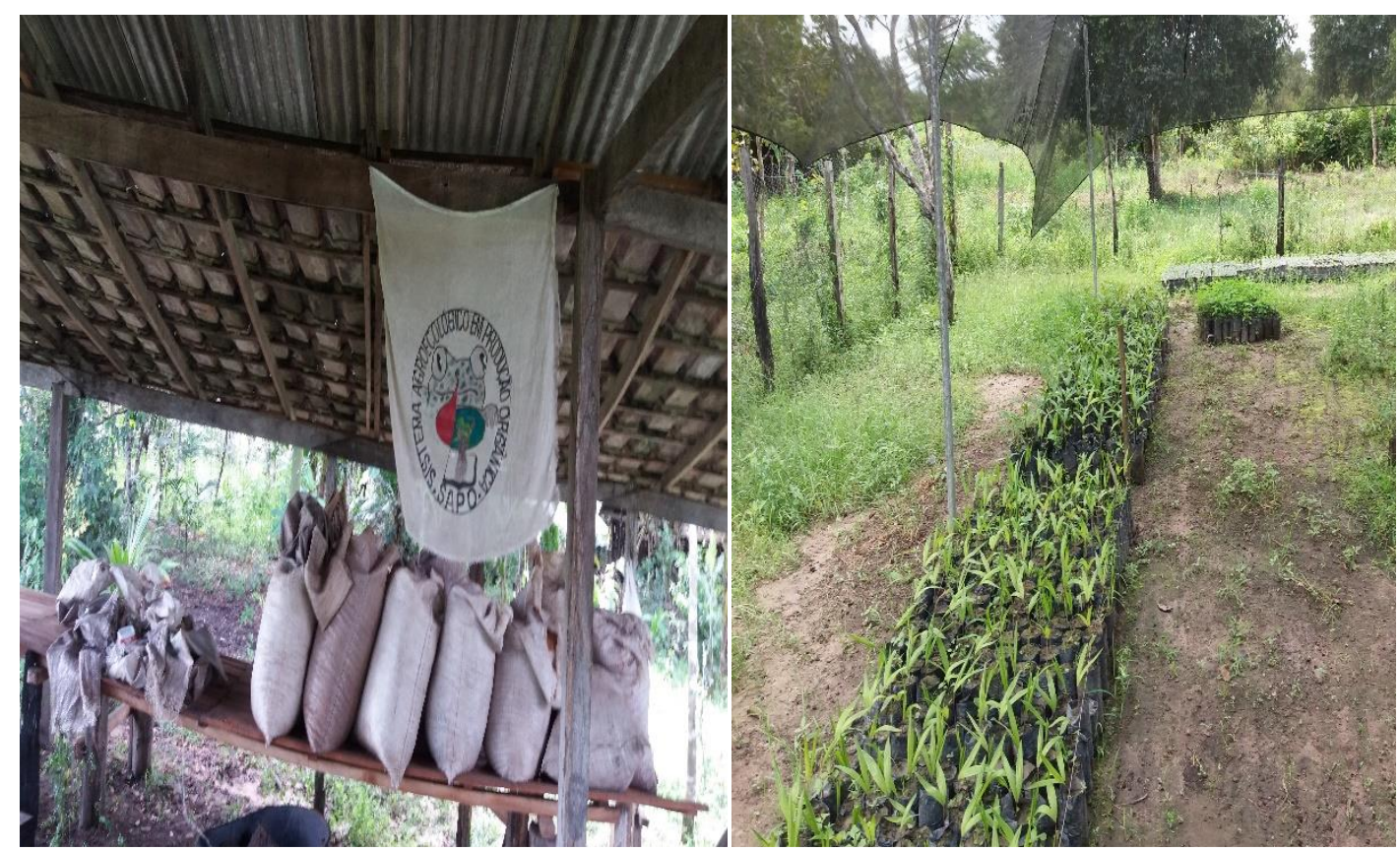

Fonte: Guilherme Junior, 2019.

Conforme foi levantado através do mais recente trabalho de campo (janeiro de 2019), majoritariamente a produção continua sendo individual (como ocorria em 2012), com pequenas ações na forma coletiva, como é o caso do SAPO. As entidades (MST e ACAJOB) permanecem atuando de maneira isolada, já que, conforme uma representante da diretoria da associação, "não participamos com eles" (Entrevistada A. em 2019), referindo-se a iniciativa do coletivo do SAPO e acrescenta "eles têm os projetos mais não discutem com a gente". Além da atuação de forma individualizada, alguns problemas identificados em 2012 permanecem, tais como: aluguel de pasto para fazendeiros vizinhos, endividamento bancário, degradação ambiental do solo, falta de água nos lotes, dificuldade no escoamento da produção e os baixos preços praticados pelos atravessadores. Deste modo, em termos produtivos o assentamento ainda precisa avançar, haja vista que, das 157 famílias participantes do assentamento somente trinta e cinco possuem produção agrícola nos seus lotes, o restante ainda depende de programas sociais ou ajuda de familiares. No que diz respeito a organização dos trabalhadores a fragmentação política ainda permanece, visto que as entidades mantem iniciativas isoladas que objetivam atender aos participantes de seus grupos, seja enquanto coletivo (SAPO/MST) ou como associação (APROCJOB). 


\section{Considerações finais}

O desenvolvimento territorial é um conceito em disputa na definição das políticas públicas e no debate acadêmico. No entanto, quando encaramos a realidade das áreas de reforma agrária, elementos fundamentais que estruturam o espaço agrário como o conflito, a precariedade da assistência técnica, as dificuldades de produzir e comercializar a produção e, em alguns casos, o baixo nível organizativo dos sujeitos e a disputa política pelo poder são fatores que impactam diretamente no desenvolvimento.

Também é fundamental pensar o desenvolvimento como um elemento baseado na multidimensionalidade do território camponês, tendo as dimensões produtiva, ambiental, política, cultural e humana. É nesta perspectiva que os sujeitos vão se formando como defensores da reforma agrária e como sujeitos políticos de transformação do mundo desde o processo de início da luta pela terra, o que não impede que descensos e conflitos sejam aflorados durante o processo.

Mesmo considerando que a produção permaneça como um elemento central na perspectiva do desenvolvimento territorial de qualquer assentamento, esse processo de organização da produção demanda a disposição social dos camponeses, posto que, as associações, cooperativas e coletivos são organizações de grande importância na relação dos trabalhadores com o Estado, o mercado e as práticas produtivas. No caso analisado, a fragmentação política gerou conflitos e o enfraquecimento das entidades, que não conseguiram superar suas diferenças, diminuindo o poder de ação e mobilização dos trabalhadores.

Conforme exposto, no Assentamento João Batista II os desafios já iniciam no processo de ocupação, pois a falta de recursos para produzir e manter as famílias marcou a vida dos trabalhadores. Quando o assentamento se estruturou, com a delimitação do número de famílias, a liberação dos recursos financeiros, a eficiências nos investimentos e o suporte na infraestrutura energética levam os três projetos (açaí, gado e lavoura branca) ao fracasso produtivo. Em um contexto mais recente a fragmentação nas ações do coletivo e da associação ainda permanecem como marca de um processo de divisão política no interior do assentamento. Para que haja desenvolvimento territorial rural é necessário que as ações triangulem de maneira eficiente a cooperação entre as entidades de representação, a comunidade e o Estado através das políticas públicas para o campo. 


\section{Agradecimentos}

Ao professor João Cleps Junior que de maneira muito gentil sugeriu modificações ao texto, colaborando para o aprimoramento do mesmo. Ao professor Fábio Luiz Zeneratti que fez sugestões relevantes colaborando para o aprimoramento do texto na versão final.

\section{Referências}

ABRAMOVAY, R. Paradigmas do capitalismo agrário em questão. $3^{\text {a }}$. ed. São Paulo: Edusp, 2012.

ARAÚJO, S M. Formas de organização da produção apoiadas pelo MST: Assentamento João Batista II, Castanhal, Pará. Belém, 2005. (Dissertação).

BERGAMASCO, S.M; NORBER, L. O que são assentamentos rurais. São Paulo: Brasiliense, 1996.

BRANDÃO, C. R. Território \& desenvolvimento: as múltiplas escalas entre o local eo global. Editora da UNICAMP, 2007.

BRINGEL, F. O.; NEVES, E. C. C.; BRITO, A. E. M.. Eles não vieram, eles chegaram: a territorialização dos camponeses no sudeste do Pará na Palmares II - Paraupebas/PA. Campo-Território, v. 12, p. 152-180, 2017.

CAMPOS, J. F. de S.; FERNANDES, B. M. O conceito de paradigma na geografia: limites, possibilidades e contribuições para uma interpretação da geografia agrária. Campo-Território: revista de geografia agrária, v. 6, n. 11, p. 21-52, fev., 2011.

CARDOSO, A. Plano de Desenvolvimento do Projeto de Assentamento João Batista II- Castanhal/PA. Belém: INCRA/FADESP/UFPA, 2001.

CHAYANOV, A. V. La organización de la unidad economica campesina. Buenos Aires: Ediciones Nueva Vision, 1974.

CHAYANOV, A. V. Teoria dos sistemas econômicos não capitalistas. In: CARVALHO, H. M. D. Chayanov e o campesinato. São Paulo, SP: Expressão Popular, 2014a. p. 99-137.

CHAYANOV, A. V. Viagem do meu irmão Alexei ao país da utopia camponesa. In: CARVALHO, H. M. D. Chayanov e o campesinato. São Paulo, SP: Expressão Popular, 2014b. p. 41-98.

COCA, E. L. F.. As disputas paradigmáticas e o conceito de desenvolvimento territorial. Revista Eletrônica da Associação dos Geógrafos Brasileiros, Seção Três Lagoas, v. 1, p. 34-55, 2015.

COELHO, F.; CAMACHO, R. S. (Org.). O campo no Brasil contemporâneo: do governo FHC aos governos petistas. 1ed.Curitiba: CRV, 2018. 
CONCRAB. Uma concepção de Desenvolvimento Rural. São Paulo: Concrab, 1998.

(Caderno de Cooperação Agrícola nº 1).

FABRINI, J. E. O projeto do MST de desenvolvimento territorial dos assentamentos e campesinato. Terra livre, São Paulo, ano 18, n. 19, p. 75-94, jul./dez. 2002.

FABRINI, J. E. Território, Casse e Movimentos Sociais no Campo. Revista da ANPEGE, v. 7, n. 7, p. 97-112, jan./jul. 2011. Disponível em:

http://anpege.org.br/revista/ojs-.2.2/index.php/anpege08/article/view/126/RA7h. Acesso em: 23. Dez. 2011. 13: 14: 45.

FAVARETO, A. D. S. Paradigmas do desenvolvimento rural em questão: do agrário ao territorial. São Paulo: Programa de Pós-Gradiação em Ciências Ambientais / USP, 2006.

FERNANDES, B. M. A formação do MST no Brasil. Petrópolis: Vozes, 2000.

FERNANDES, B. M. Conflitualidades, reforma agrária e desenvolvimento. CampoTerritório: revista de geografia agrária. Edição especial do XXI ENGA-2012, p. 1-10, jun., 2014.

FERNANDES, B. M. Construindo um estilo de pensamento na questão agrária: o debate paradigmático e o conhecimento geográfico (tese de livre-docência). Presidente Prudente (SP): UNESP, v. 1-2: il + memorial, 2013.

FERNANDES, B. M. Entrando nos territórios de território. In: PAULINO, E. Tomas; FABRINI, J. Edmilson (Org). Campesinato e territórios em disputa. São Paulo: Ed. Expressão Popular, 2008. P. 273-301.

FLICK, U. Desenho da pesquisa qualitativa. Porto Alegre: Artmed, 2009.

GUILHERME JR. J. A. Reprodução camponesa em área de assentamento na Amazônia: um estudo no Assentamento João Batista II, Castanhal - Pará. Dissertação (Mestrado) - Universidade Federal do Pará, Instituto de Filosofia e Ciências Humanas, Programa de Pós-Graduação em Geografia, Belém 2013.

HAESBAERT, R. O Mito da Desterritorialização: do fim dos territórios à multiterritorialização. Rio de Janeiro: Bertrand Brasil, 2004.

KAUTSKY, K. A questão Agrária. São Paulo, SP: Nova Cultural, 1986.

LAMARCHE, H. A agricultura familiar: do mito à realidade. Campinas: Editora da Unicamp, 1998.

LAMARCHE, H. A agricultura familiar: uma realidade miltiforme. Campinas: Editora da Unicamp, 1993. 
LÊNIN, V. I. Capitalismo e agricultura nos Estados Unidos da América: novos dados sobre as leis de desenvolvimento do capitalismo na agricultura. São Paulo, SP: Brasil Debates, 1980.

LÊNIN, V. I. O desenvolvimento do capitalismo na Rússia. São Paulo, SP: Nova Cultural, 1985.

LUXEMBURG, R. A acumulação do capital. São Paulo, SP: 1985, 1985.

MARQUES, M. I. M. A atualidade do uso do conceito de camponês. Presidente Prudente: Revista NERA, Ano 11, no. 12, pp. 57-67, Jan.-jun./2008.

MENDRAS, H. La fin des paysans. Paris: Actes Sud, 1984.

NAVARRO, Z. Desenvolvimento rural no Brasil: os limites do passado e os caminhos do futuro. Estudos Avançados. Vol. 15 n. 43. São Paulo.

Setembro/dezembro 2001.

OLIVEIRA NETO, A. Territórios Subordinados: análise da política de desenvolvimento territorial a partir da produção de óleo de palma pela Agropalma em assentamentos de reforma agrária no Pará. Tese (doutorado em geografia). Programa de Pós-Graduação em Geografia. Universidade Estadual Paulista "Júlio de Mesquita Filho", Campus Presidente Prudente, 2017.

OLIVEIRA, A. U. Modo capitalista de produção e agricultura. Vol. 68. Editora Ática, 1986.

ORTEGA, A. C. Territórios Deprimidos: desafios para as políticas de desenvolvimento rural. Campinas, SP: Alínea, 2008.

SAQUET, M. A. Campo-Território: considerações teórico-metodológicas. In.: CampoTerritório: Revista de Geografia Agrária, Uberlândia, v. 1, n. 1, p. 60-81, fev. 2006.

SCHNEIDER, S., TARTARUGA, I.G.P. Território e Abordagem Territorial: das referências cognitivas aos aportes aplicados à análise dos processos sociais rurais. Raízes. v.23, n.1, p.99-116, 2004.

SHANIN, T. Lições Camponesas. In: PAULINO, E.T.; FABRINI, J.E. (orgs.) Campesinato e territórios em disputas. São Paulo: Expressão Popular, 2008. p. 23-48. SILVA, E. R. F.; HESPANHOL, R. A. de M. As políticas públicas para o meio rural no Brasil e em Portugal e suas abordagens. Campo-Território: revista de geografia agrária, v. 11, n. 22, p. 185-207, abr., 2016.

SILVA, J. M. P.; OLIVEIRA NETO, A. Por uma outra territorialização na Amazônia paraense. Revista Nera (UNESP), v. 42, p. 354-372, 2018. 
SILVA, J. M. P.; SILVA, C. N.; OLIVEIRA NETO, A.; NASCIMENTO, F. R. Conflitos pelo uso do território na Amazônia mineral. Mercator (FORTALEZA. ONLINE), v. 16, p. 1-18, 2017.

SULZBACHER, A. W.; DAVID, C. Alternativas para o espaço rural: importância de compatibilizar políticas públicas com saberes locais. Campo-Território: revista de geografia agrária, v.3, n. 5, p. 14-37, fev. 2008.

VEIGA, J. E. O desenvolvimento agrícola: uma visão histórica. São Paulo: EDUSP, 2012.

WANDERLEY, M. de N. B. Raízes históricas do campesinato brasileiro. In: XX Encontro da ANPOCS. GT 17. Processos sociais agrários. Caxambú, MG. Outubro, 1996.

ZENERATTI, F. L. A atualidade da luta camponesa na mesorregião Noroeste do estado do Paraná. Estudos Geográficos, Rio Claro, 12(2): 126-144, jul./dez. 2014. 